\title{
Customer brand engagement during service lockdown
}

Article

Accepted Version

Hollebeek, L., Smith, D., Kasabov, E., Hammedi, W., Warlow, A. and Clark, M. (2021) Customer brand engagement during service lockdown. Journal of Services Marketing, 35 (2). JSM05-2020-0199.R2. ISSN 0887-6045 doi: https://doi.org/10.1108/JSM-05-2020-0199 Available at https://centaur.reading.ac.uk/92868/

It is advisable to refer to the publisher's version if you intend to cite from the work. See Guidance on citing.

To link to this article DOI: http://dx.doi.org/10.1108/JSM-05-2020-0199

Publisher: Emerald

All outputs in CentAUR are protected by Intellectual Property Rights law, including copyright law. Copyright and IPR is retained by the creators or other copyright holders. Terms and conditions for use of this material are defined in the End User Agreement.

\section{www.reading.ac.uk/centaur}

\section{CentAUR}

Central Archive at the University of Reading 
Reading's research outputs online 


\title{
Customer brand engagement during service lockdown
}

\begin{abstract}
Purpose: While customer brand engagement (CBE) research has advanced important insight, most studies to-date explore CBE under regular, free-market conditions, yielding an important knowledge gap regarding its manifestation under less regular conditions, including disaster/pandemics. We therefore explore CBE with essential/non-essential service during COVID-19-prompted citizen lockdown.
\end{abstract}

Design/methodology/approach: Based on a review, we develop a framework of lockdownbased CBE with essential/non-essential service interactions, which are conceptualized by their respective capacity to meet differing needs in Maslow's hierarchy. We view lockdown-based essential/non-essential service interactions to differentially impact CBE, as summarized in a set of Propositions.

Findings: The framework depicts lockdown-based essential/non-essential service interactions and their respective impact on $\mathrm{CBE}$. We propose two essential service modes (i.e., socially distant/platform-mediated interactions) and two non-essential service modes (i.e., service closure/platform-mediated interactions), which we hypothesize to differently affect CBE. Moreover, we view the associations between our lockdown-based service modes and CBE to be moderated by customers' regulatory focus (i.e., promotion/prevention), as formalized in our Propositions.

Research limitations/implications: Given our focus on lockdown-based CBE, this paper adds unique insight to the literature. It also raises ample opportunities for further study, as outlined.

Practical implications: This research yields important managerial implications, including the suggested adoption of differing tactics/strategies to leverage promotion/prevention-focused customers' brand engagement during lockdown.

Originality/value: By exploring the effects of lockdown-based essential/non-essential service interactions on promotion/prevention-focused customers' brand engagement, this paper adds novel insight.

Keywords: Customer brand engagement, lockdown, (non-)essential service, COVID-19, regulatory focus theory, social distancing, platform-mediated service, Maslow's needs hierarchy.

Paper type: Conceptual paper. 


\section{Introduction}

Customer brand engagement (CBE), which exposes a client's "investment of operant resources (i.e., cognitive, emotional, behavioral, and/or social knowledge/skills) and operand resources (e.g., equipment) in [their] brand interactions" (Kumar et al., 2019, p. 141), has received widespread attention (Furrer et al., 2020). Given its interactive core, CBE has prime applicability in the service context that is characterized by high interactivity, including among customers, service staff, and fellow customers (Oertzen et al., 2020; Clark et al., 2020).

Existing CBE literature has developed important acumen, including by defining and operationalizing the concept, and outlining its contribution to key firm performance indicators, including sales (Brodie et al., 2011; Letheren et al., 2019). However, most studies to-date address $\mathrm{CBE}$ under regular, free-market conditions characterized by relatively plentiful resources/offerings and free choice (Hollebeek et al., 2019; Ward et al., 2019). Consequently, understanding of CBE under less regular or -predictable conditions remains limited. Important exceptions to this observation include Beckers et al.'s (2018) and Yuan et al.'s (2020) exploration of firm advertising's effect on CBE in the context of product-harm crises, and Karpen and Conduit's (2020) discussion of COVID-19-based CBE. However, though the latter authors adopt economic rationalism, institutionalism, and existential humanism to explore $\mathrm{CBE}$ during COVID-19, they do not specify how customers are expected to engage with their service brands during pandemic-instigated lockdown, as undertaken in this paper.

Based on this gap, we explore CBE during citizen lockdown, as implemented in many countries globally during the COVID-19 pandemic (Heymann and Shindo, 2020), and highlight its unique lockdown-based dynamics. The paper makes the following contributions. First, as stated, we add to CBE-based insight by exploring service provision during choiceconstraining, obligatory citizen lockdown imposed by COVID-19, which may return in future emergency- or crisis-prompted lockdown. Lockdown offers an interesting case for further 
exploration, as it relegates CBE's typically more volitional nature under regular market conditions. Our analyses therefore extend Hollebeek et al.'s (2018) notion of boundedly volitional $\mathrm{CBE}$, which recognizes that while $\mathrm{CBE}$ has an important voluntary (i.e., free choicebased) facet (e.g., customers choosing their preferred brand), it may also contain an involuntary aspect (e.g., restricted face-to-face service interactions during lockdown). Given its likely adjusting effect on the ratio of voluntary-to-non-voluntary CBE (vs. under regular market conditions), lockdown offers a thought-provoking scenario for further exploration, as therefore addressed in this paper.

Second, given government-enforced, COVID-19-based lockdown requirements on citizens in many countries, we develop a model of CBE with essential/non-essential service interactions during lockdown. Lockdown refers to people being instructed to "self-isolate" at home as much as possible by only going out to shop for essential supplies, practising social distancing by keeping an at least 1.5-2 metre distance from others, and limiting their face-toface interactions (and thus, engagement) to those in their bubble (i.e., lockdown cohabitants; WHO, 2020). In lockdown, non-essential (e.g., tourism) services are closed and social gatherings are forbidden to limit the pandemic's spread.

As discussed in section 3.1, government-designated essential service satisfies consumers' basic physiological- (e.g., sustenance) or safety needs (e.g., housing; Maslow, 1943). By contrast, non-essential service either gratifies physiological or safety needs in beyond-basic ways (e.g., dining out) or fulfils Maslow's higher-order needs of love/belonging, esteem, or self-actualization. During lockdown, only essential service remains open in many countries, including parts of China, the United States, Italy, Spain, France, and Germany, but typically with social distancing restrictions (Sullivan et al., 2020), thus impacting interactive CBE. Moreover, during lockdown, non-essential service is required to either temporarily close, or be delivered via platform-mediated interactions (Ramaswamy and Ozcan, 2016). We expect 
locked-down customers to engage differently with essential and non-essential service brands (vs. under regular market conditions), as explored further in this paper.

Based on this rationale, we develop a framework that maps CBE with essential/nonessential service brands during lockdown. Here, essential service transpires via (a) socially distant interactions (e.g., at supermarkets) and/or (b) platform-mediated interactions, including by phone, email, websites, social media, service robots, etc. (e.g., online grocery ordering; Lee et al., 2020). Non-essential service is either (a) temporarily closed during lockdown, or (b) available (to some degree) via platform-mediated service interactions. In this paper, we theorize about the impact of these lockdown-based service modes on CBE.

We further propose that $\mathrm{CBE}$ with essential/non-essential service brands is moderated by customers' regulatory (i.e., promotion/prevention) focus (Higgins, 1997), as discussed in section 2.2. Though prior studies have linked regulatory focus and CBE (e.g., Mosteller and Poddar, 2017), they are yet to apply this interface to the unique, volitional CBE-constrained conditions imposed by pandemic-prompted lockdown, as explored in this paper.

The paper is structured as follows. Section 2 reviews relevant CBE/regulatory focus theory literature. In section 3.1, we conceptualize essential/non-essential service, as derived from Maslow's needs hierarchy, and propose four lockdown-based essential/non-essential service modes. We then develop a framework (Figure 1) that maps the impact of these service modes on $\mathrm{CBE}$, with the respective associations being moderated by customers' regulatory focus. In section 3.2, we summarize the framework's associations in a set of Propositions, followed by an outline of implications that arise from this research in section 4 .

\section{Literature review}

\subsection{Customer brand engagement}


As stated, CBE has been defined as a customer's resource investment in his/her brand interactions (Kumar et al., 2019; Hollebeek et al., 2019; Hollebeek and Chen, 2014), highlighting its interactive nature that differentiates it from related concepts, including involvement or commitment (Brodie et al., 2011, 2013). Goffman (1969) views interaction as an interpersonal communication, thus incorporating both face-to-face and remote (e.g., platform-mediated) interactions within its scope.

Our review highlights the following CBE hallmarks. First, CBE's resource investments vary in their volitionality level (Hollebeek et al., 2018), as outlined. While some resource investments are made voluntarily, others can be required or controlled by others. For example, customers selecting their favorite brand (i.e., voluntary investment), versus clients being required to pay for on-service site parking (i.e., less voluntary investment). Under regular, freemarket conditions, CBE's volitionality level can be constrained by such factors as institutions (e.g., rules/control) or lacking (e.g., financial) resources (Vargo and Lusch, 2016; Kasabov and Warlow, 2010; Kasabov and Da Cunha, 2014). However, during lockdown, CBE's voluntariness is further restrained by service system (i.e., government)-imposed limitations, including temporary service closure and forbidden social interactions and travel (Baker, 2020), thus further impacting CBE.

Second, CBE has been viewed as a multidimensional concept (e.g., Vivek et al., 2014; Juric et al., 2016), which comprises customers' cognitive, emotional, and behavioral resource investments in their interactions (Clark et al., 2020; Hollebeek, 2011a/b). For example, customers might invest their reading/scrolling skills to get the latest news on their smartphone. While some researchers single out behavioral engagement (Do et al., 2020; Groeger et al., 2016), others extend the multi-dimensional CBE model by adding a social dimension that highlights customers' communal, collective, or shared resource investments (e.g., user bonding in online communities; Khan et al., 2020; Brodie et al., 2013). Though we agree with the 
widely-cited, three-dimensional view of CBE (Harrigan et al., 2018; Hollebeek et al., 2014), we primarily focus on behavioral $\mathrm{CBE}$, given its focus on directly observable CBE expressions (Verleye et al., 2014). We next review CBE's interface with regulatory focus theory.

\subsection{The CBE/regulatory focus theory interface}

CBE has been examined from several theoretical perspectives, including S-D logic, social exchange theory, and regulatory focus theory, to name a few (Brodie et al., 2011; Solem and Pedersen, 2016; Eberhardt et al., 2020). Higgins' (1997) regulatory focus theory explores the association between individuals' values/beliefs-based motivation and their goal fulfilment processes, which service customers largely seek through value-laden brand/firm interactions, thus affecting CBE (Higgins and Scholer, 2009). Based on regulatory focus theory, customers are assumed to embrace pleasure, but avoid pain when engaging with their brands, and their chosen mechanism to achieve this goal reveals their regulatory focus (Eberhardt et al., 2020).

Regulatory focus theory proffers two self-regulatory mechanisms: Promotion and prevention. Promotion-focused individuals emphasize the achievement of gains (e.g., hopes, accomplishments; Higgins, 1997). In marketing, customers' promotion focus manifests through eager or (pro)active strategies to achieve their goal (e.g., by engaging in brand-related citizenship behaviors to optimize their service experience; Solem and Pedersen, 2016). Promotion-focused customers therefore commit resources (i.e., engage) to optimize their service experience (Kumar et al., 2019; Hollebeek, 2013), including through lockdown.

However, prevention-focused individuals emphasize the pursuit of security or responsibilities to avoid loss (Higgins, 1997). Prevention-focused consumers tend to accept and follow the rules by adopting vigilant strategies (e.g., by adhering to lockdown instructions) to achieve their goal (e.g., remaining virus-free). That is, unlike promotion-focused customers, who seek to boost hedonic, functional, or social gains from their brand interactions, prevention- 
focused customers invest to avert or minimize pain or loss in their lockdown-based service interactions (Higgins and Scholer, 2009). Based on these foundations, we next develop a framework of promotion/prevention-focused customers' brand engagement with essential/nonessential service brands through lockdown.

\section{Conceptual framework}

Our framework maps CBE with essential/non-essential service during COVID-19prompted lockdown (see Figure 1). Section 3.1 conceptualizes essential/non-essential service, as linked to Maslow's (1954) needs hierarchy, as outlined. Relatedly, we develop four lockdown-based essential/non-essential service modes, as discussed in sections 3.1.1 and 3.1.2, respectively. In section 3.2, we explore the impact of these service modes on $\mathrm{CBE}$, as moderated by the customer's regulatory focus, which we summarize in a set of Propositions.

\section{Figure 1 about here}

\subsection{Essential vs. non-essential service}

We conceptualize essential and non-essential service by examining which of Maslow's (1954) needs a service meets (see Figure 1). The inverted or upside-down depiction of Maslow's hierarchy highlights the particular importance of essential (vs. non-essential) service, which continues to be provided during lockdown. As outlined, essential service offers basic fulfilment of Maslow's (1943) physiological or safety needs. Physiological needs reflect an individual's physical survival requirements, including basic nourishment (e.g., supermarket supplies), hydration, sleep, and clothing. These universal human needs must be met before higher-order needs can be satisfied. When these are met, individuals' safety needs surface, which reveal the need to be safe from harm (e.g., need for a safe, secure environment; Maslow, 1954). 
Non-essential service either meets Maslow's physiological or safety needs in beyondbasic ways (e.g., dining out) or fulfils the higher-order needs for love/belonging, esteem, or self-actualization, as outlined. Love/belonging needs reflect a customer's desire for friendship, intimacy, or family, as catered for by - for instance - dating services or online community memberships. Esteem needs reflect a customer's ego- or status needs, including by desiring others' acceptance or respect (e.g., catered for by beauty services; Maslow, 1943). Finally, selfactualization needs reflect a customer's desire to realize his/her full potential, including by pursuing one's personal goals or nurturing one's talents (e.g., catered for by self-development courses; Maslow, 1954). While many non-essential services that require face-to-face interactions (e.g., hairdressing/massage therapy) remain temporarily closed, other services that can be conducted via technology-mediated platforms may continue online through lockdown (e.g., virtual counseling sessions; Békés and Aafjes-Van Doorn, 2020), thus differentially affecting CBE. We next introduce four key lockdown-based essential/non-essential service modes, followed by a discussion of their respective effects on CBE.

\subsubsection{Essential service}

We propose two lockdown-based essential service modes. First, essential service may be offered through government-imposed socially distant interactions, where providers' bricksand-mortar stores remain open for face-to-face, but restricted interactions, in which (frontline) staff and customers must practise social distancing (Wilder-Smith et al., 2020). Here, only few customers are permitted in-store at a time, customers are required to limit their store visits, both in terms of visit frequency and time spent in-store, and service staff/customers are typically required to keep a physical distance from one another and wear protective equipment (e.g., gloves, face mask). The provider's usual service portfolio may also be temporarily narrowed during lockdown, and more stringent hygiene procedures tend to be enforced (Lin et al., 2020). 
Second, essential service can be implemented through platform-mediated interactions, which deploy technological touch-points, including firm phone numbers, (e-commerce) websites, social media pages, mobile apps, service robots, etc. to facilitate service interactions (Breidbach et al., 2014). For example, many locked-down customers are migrating their grocery shopping to their retailer's online platform (vs. physical store visits; Marston et al., 2020). Unlike its socially distant counterpart, lockdown-based platform-mediated service interactions remain relatively unrestricted (e.g., in terms of customers' time allowance to complete their order). Overall, many essential service providers offer socially distant, on-site and platform-mediated service interactions during lockdown.

\subsubsection{Non-essential service}

Non-essential service also sees two lockdown modes. First, government-imposed service closure requires businesses to temporarily close their physical premises, where faceto-face service interactions would ordinarily take place (e.g., travel agencies, gyms). Closure is justified based on the service's non-essential nature (i.e., it does not satisfy consumers' basic physiological or safety needs), and the risk of it contributing to the pandemic's further dissemination if it remained open (Baker, 2020).

Second, like essential service, non-essential service can be provided through platformmediated interactions. For example, global fitness franchise Les Mills offers its exercise classes online to locked-down consumers, and via television in some countries (Heard, 2020), thus continuing to engage existing, and possibly attracting new, clients (Hammedi et al., 2015). However, while non-essential services' platform-mediated interactions can be firm-instigated, locked-down consumers may also initiate platform-mediated, non-essential service interaction substitutes (e.g., by virtually exercising with their gym buddies). We next explore the effects of our lockdown-based essential/non-essential service modes on CBE. 


\subsection{Impact of lockdown-based service modes on CBE}

Below, we infer the impact of our lockdown-instigated essential and non-essential service modes on $\mathrm{CBE}$ (see sections 3.2.1-3.2.2, respectively), which we posit to be moderated by customers' regulatory focus.

\subsubsection{Essential service}

As discussed, lockdown-based essential service transpires via socially distant or platform-mediated interactions (also see Figure 1). Their respective effects on promotion/prevention-focused individuals' CBE are discussed further below.

\section{Impact of socially distant service interactions on promotion/prevention-focused CBE.}

We first address the effect of lockdown-imposed socially distant, essential service interactions on promotion/prevention-focused customers' brand engagement (see Figure 1: top left). As outlined in section 3.1.1, socially distant service interactions require customers' physical distance from each other and service employees while on-site. Section 2.2 also reported that promotion-focused customers adopt eager, proactive strategies to optimize their service interactions (Solem and Pedersen, 2016).

While promotion-focused customers actively want to invest in their service interactions (Sprott et al., 2020), lockdown-imposed social distancing limits these customer investments in their remaining face-to-face service interactions (e.g., grocery shopping). We therefore expect these keen customers to seek fulfilment by engaging with essential service brands in alternate ways, including through platform-mediated interactions (e.g., by registering on the brand's website or joining online brand communities to optimize their brand experience during lockdown; Solem and Pedersen, 2016; Liberman et al., 2001). Therefore,

P1: To compensate for CBE-limiting socially distant service interactions, locked-down, promotion-focused customers will engage in a broader range of platform-mediated essential service interactions (vs. under regular market conditions). 
Prevention-focused customers, however, focus on avoiding loss, and vigilantly pursue security and responsibilities, and follow rules (Higgins, 1997), including those relating to COVID-19-prompted social distancing. While these customers' loss-avoidant stance typically implies their concern regarding a range of perceived risks under regular market conditions (e.g., psychological/social risk; Jacoby and Kaplan, 1972; Hollebeek et al., 2020), in lockdown, their loss-avoidant position shifts to primarily focus on minimizing basic physiological or safety risks (e.g., remaining virus-free), versus risk associated with Maslow's higher-order needs (cf. Markowitz et al., 2014). Therefore, during lockdown,

P2: Socially distant essential service interactions lead prevention-focused customers to primarily engage in mitigating brand-related physiological or safety risk (vs. risk associated with their higher-order needs).

Impact of platform-mediated service interactions on promotion/prevention-focused

$\boldsymbol{C B E}$. Second, we address the effect of platform-mediated essential service interactions on promotion/prevention-focused customers' brand engagement (see Figure 1: top center). As discussed in section 3.1.1, platform-mediated service interactions deploy technological platforms (e.g., websites, apps) to interact with customers (Ramaswamy and Ozcan, 2016; Beck et al., 2020). Moreover, promotion-focused customers' eager strategies will see them explore different ways to interact with or experience their service brands (Higgins, 1997).

P1 stipulated that locked-down, promotion-focused customers engage in more platform-mediated interactions with essential service brands than usual. Given these customers' active, resourceful stance (Solem and Pedersen, 2016; Liberman et al., 2001), their platform-mediated interactions are likely to extend beyond those with the brand/firm alone, to ones with other actors (e.g., by exchanging brand-related ideas (e.g., recipes) with fellow customers; Clark et al., 2020; Alexander et al., 2018; Rosenbaum and Massiah, 2007). To fulfil these customers' desire to optimally experience their service brands during lockdown, 
P3: Promotion-focused customers' brand engagement in platform-mediated, essential service interactions sees a broader range of new or alternate brand-related uses and applications (vs. under regular market conditions).

However, loss-avoidant, prevention-focused customers typically use fewer brandrelated, technology-mediated platforms than their promotion-focused counterparts, as they are more likely to limit their interactions to trusted platforms (Das, 2016). Consequently, we expect them to experience higher levels of technology-related discomfort or insecurity (Parasuraman, 2000), particularly for new or unknown platforms. They are also more likely to delay adopting brand-related, technology-mediated platforms until they are mainstream, rendering them less likely to be technology innovators or early adopters (Rogers, 1962).

However, as outlined in P2, prevention-focused customers' perceived risk of contracting the virus during lockdown is likely to outweigh their technological reservations, particularly for essential service, for which they are now much more reliant on technologymediated platforms (vs. under regular market conditions; KPMG, 2020). Therefore, during lockdown, these customers' opportunity to delay the uptake of essential service-based, platform-mediated interactions (e.g., online grocery ordering) is significantly reduced (vs. under regular market conditions; e.g., Stam and Stanton, 2010). Consequently, we expect locked-down, prevention-focused customers' greater reliance on platform-mediated essential service interactions to help overcome their platform-related technological discomfort and insecurity (Parasuraman, 2000). Thus, during lockdown,

P4: Prevention-focused customers' brand engagement in platform-mediated, essential service interactions increases more rapidly (vs. under regular market conditions).

\subsubsection{Non-essential service}

Non-essential service is either temporarily closed, or transpires through platformmediated service interactions during lockdown (see Figure 1). Their respective effects on promotion/prevention-focused individuals' CBE are outlined below. 
Impact of temporary service closure on promotion/prevention-focused CBE. We next address the effect of lockdown-imposed, temporary non-essential service closure on promotion/prevention-focused customers' brand engagement (see section 3.1.2; Figure 1: bottom of triangle). As stated, non-essential service either gratifies consumers' physiological or safety needs in beyond-basic ways, or fulfils their higher-order love/belonging-, esteem-, or self-actualization needs (e.g., luxury hotel stays).

Temporary non-essential service closure affects those businesses that national governments have ordered to cease operating during lockdown to minimize the risk of the pandemic spreading (Heymann and Shindo, 2020). Therefore, face-to-face service interactions are unavailable during lockdown. Given promotion-focused customers' eager stance (Micu and Chowdhury, 2010), they will likely seek brand-related fulfilment in alternate ways, particularly for their preferred brands (P3), thus elongating their engaged timespan even through lockdown. We however infer that prevention-focused customers tend to be more accepting of temporary service closure during lockdown. That is, they are more likely to be happy to wait to resume their non-essential service interactions post-lockdown (Solem and Pedersen, 2016), thus potentially yielding a period of CBE dormancy during lockdown (Brodie et al., 2013). Therefore, during lockdown,

P5: Prevention (vs. promotion)-focused customers' engagement with a temporarily closed, desired non-essential service brand is more (vs. less) likely to see a period of CBE dormancy.

\section{Impact of platform-mediated service interactions on promotion/prevention-focused}

$\boldsymbol{C B E}$. Fourth, we address the effect of lockdown-imposed, platform-mediated interactions for non-essential service on promotion/prevention-focused customers' brand engagement (see section 3.1.2; Figure 1: bottom of triangle). As many non-essential (e.g., tourism, beauty) services are experiential to customers or facilitate their self-expression (Sprott et al., 2009), eager, promotion-focused customers, in particular, will miss experiencing the full range of their 
non-essential service benefits during lockdown. Therefore, they are likely to engage in alternate (e.g., platform-mediated) brand interactions as a substitute (Werth and Foerster, 2007). Thus, in lockdown,

P6: Promotion-focused customers' engagement with their desired non-essential service brands through platform-mediated interactions is higher (vs. under regular market conditions).

Moreover, while platform-mediated essential service interactions are rapidly becoming the new normal, non-essential service transpiring through platform-mediated interactions remains more discretionary to customers. Given prevention-focused customers' more riskaverse stance (Solem and Pedersen, 2016) and slower technological uptake (Rogers, 1962), as discussed, we posit that during lockdown,

P7: Promotion (vs. prevention)-focused customers' engagement with their desired nonessential service brands through platform-mediated interactions will be higher.

In sum, P6-7 propose that during lockdown, promotion-focused customers' engagement with non-essential service brands through platform-mediated interactions is not only higher than usual, but it also exceeds that of prevention-focused customers. We next synthesize important implications that arise from this research.

\section{Discussion, implications, and limitations}

\subsection{Theoretical implications}

Our framework maps the impact of our four lockdown-imposed essential/non-essential service modes on promotion/prevention-focused customers' brand engagement. As such, it makes an important contribution to the $\mathrm{CBE}$ literature, which has primarily addressed $\mathrm{CBE}$ under regular, free-market conditions to-date.

To conceptualize essential/non-essential service, we draw on Maslow's (1943, 1954) hierarchy of needs, thereby generating two lockdown-based essential service modes (i.e., socially distant/platform-mediated interactions), and two non-essential service modes (i.e., 
service closure/platform-mediated interactions), as shown in Figure 1. In the current COVID19 landscape and beyond, our conceptualization of essential/non-essential service and their respective sub-types hold significant value. That is, a sound understanding of essential (vs. non-essential) service is important in handling and resolving the current pandemic (Ma et al., 2020). Moreover, future disasters or crises may see a renewed need to draw on our essential/non-essential service typology (Hambrick, 1984) and explore the effects of its respective components on $\mathrm{CBE}$, corroborating its value both during and beyond COVID-19.

Second, based on the framework, we developed a set of Propositions that outline the effects of our lockdown-prompted service modes on promotion/prevention-focused customers' brand engagement. Given COVID-19's rapid, unanticipated surge, these Propositions offer important, novel CBE-based insight in cases of national or global emergency, including catastrophes or pandemics, which has lagged behind to-date. By mapping promotion- and prevention-focused individuals' $\mathrm{CBE}$ in essential/non-essential service brand interactions, this study offers a springboard for further scrutiny of CBE under choice-constraining, lockdownbased market conditions. In section 4.3, we offer specific issues for further research in this vital area.

\subsection{Managerial implications}

This research also raises important practical implications. First, we inferred that not only promotion-focused $(\mathrm{P} 1,3,6)$, but also prevention-focused customers (P4) are likely to engage in a broader range of platform-mediated service interactions during lockdown (vs. under regular market conditions). Specifically, promotion-focused customers seek to optimize their brand interactions (Solem and Pedersen, 2016), which through lockdown, is best achieved by engaging in platform-mediated interactions where possible (Ramaswamy and Ozcan, 2016). By contrast, prevention-focused customers' primary desire is to remain virus-free (Higgins, 1997), to which platform-mediated service interactions are also conducive, given their lack of 
face-to-face contact. Therefore, to cater to promotion- and prevention-focused customers during lockdown, managers are advised to develop and maintain a range of service interaction platforms (Vilnai-Yavetz and Levina, 2018), including ecommerce websites, mobile apps, brand communities, or virtual reality-based touchpoints (e.g., CapGemini, 2020; Hollebeek et al., 2020; Viswanathan et al., 2017), which are instrumental in engaging these consumers.

Second and relatedly, during lockdown, many promotion- and prevention-focused customers have shifted to purchasing online (vs. in-store; Roggeveen and Sethuraman, 2020), requiring them to learn new brand-related (e.g., app navigation, usage) skills. Post-lockdown, these customers may wish to continue using their new skills, which managers can leverage by offering value-laden platform-mediated service interactions to sustain these customers' brand engagement long-term, including post-the pandemic (Porpiglia et al., 2020). For example, now that COVID-19 has raised consumer awareness of the dangers inherent in face-to-face service interactions, particularly prevention-focused customers are likely to remain more cautious regarding these, leading them to choose (more) platform-mediated (vs. physical) service interactions in the longer-term future. To sustain promotion- and prevention-focused customers' brand engagement post-the pandemic, we recommend managers to first identify those customers that have started using new brand-related platforms during lockdown, and who wish to continue using these post-lockdown, and continue targeting them with relevant brandrelated content via these platforms.

Third, locked-down, promotion-focused customers are expected to conceive of new or alternate brand-related uses, activities, or applications (P3), which managers might like to track or document. For example, to optimize their brand interactions during lockdown, promotionfocused customers may establish new brand communities to facilitate brand-related discussions with like-minded others (Hollebeek et al., 2017). Managerial tracking of and insight into such 
customer initiatives may be used to inform new promotional campaigns, formal market research, or platform- or service development post-lockdown or post-the pandemic.

\subsection{Limitations and further research}

We conclude by identifying this study's chief limitations, from which we identify avenues for further research. First, the purely conceptual nature of our analyses sparks a need for their future empirical testing and validation. Further researchers may wish to test our Propositions, or identify important additional moderating variables (e.g., culture, desire for control) that may affect or refine our findings (Kasabov and Warlow, 2010). Moreover, our adoption of Maslow's (1943) hierarchy of needs, which lacks proven cross-cultural applicability (Gambrel and Cianci, 2003), renders a need for further consideration of culture's potentially differing effects on global customer needs and CBE alike (e.g., Gupta et al., 2018; Hollebeek, 2018). Therefore, further research may wish to validate our framework in different cultural contexts.

Second, though we deployed customers' regulatory focus as a key moderator in the association of our lockdown-based service modes and CBE, an individual's regulatory fit is not fixed per se, and may also be prompted by particular stimuli. Thus, while most individuals are inclined towards either promotion or prevention (Higgins et al., 2001), their regulatory focus may vary situationally, as recognized in prospect theory (Kahneman and Tversky, 1986), which merits further study.

Third, while we focus on CBE as those (less) voluntary customer resource investments in their brand interactions (Kumar et al., 2019; Hollebeek et al., 2019), other authors view CBE to extend beyond customer brand/firm interactions alone (Vivek et al., 2012; Bowden, 2009). Therefore, future studies may wish to adopt a broader view of lockdown-based engagement that extends beyond service brand interactions (e.g., by incorporating customers' brand-related cognitive processing outside these interactions; Harrigan et al., 2018). 
Fourth, during the pandemic, many customers worldwide are stockpiling goods, leading to in-store stockouts. We offer the following questions for further research: To what extent do promotion/prevention-focused customers engage in stockpiling at differing crisis-based national emergency levels? How are supply chains best designed to cope with customer stockpiling under rising alert levels, particularly immediately prior to and during lockdown? To what extent, how, and why do locked-down customers substitute their preferred resources with others, and how does this affect their short- and long-term CBE? How does customers' fluctuating brand engagement during disaster affect their wellbeing (Russell-Bennett et al., 2019)? 


\section{Figure 1: Conceptual framework}

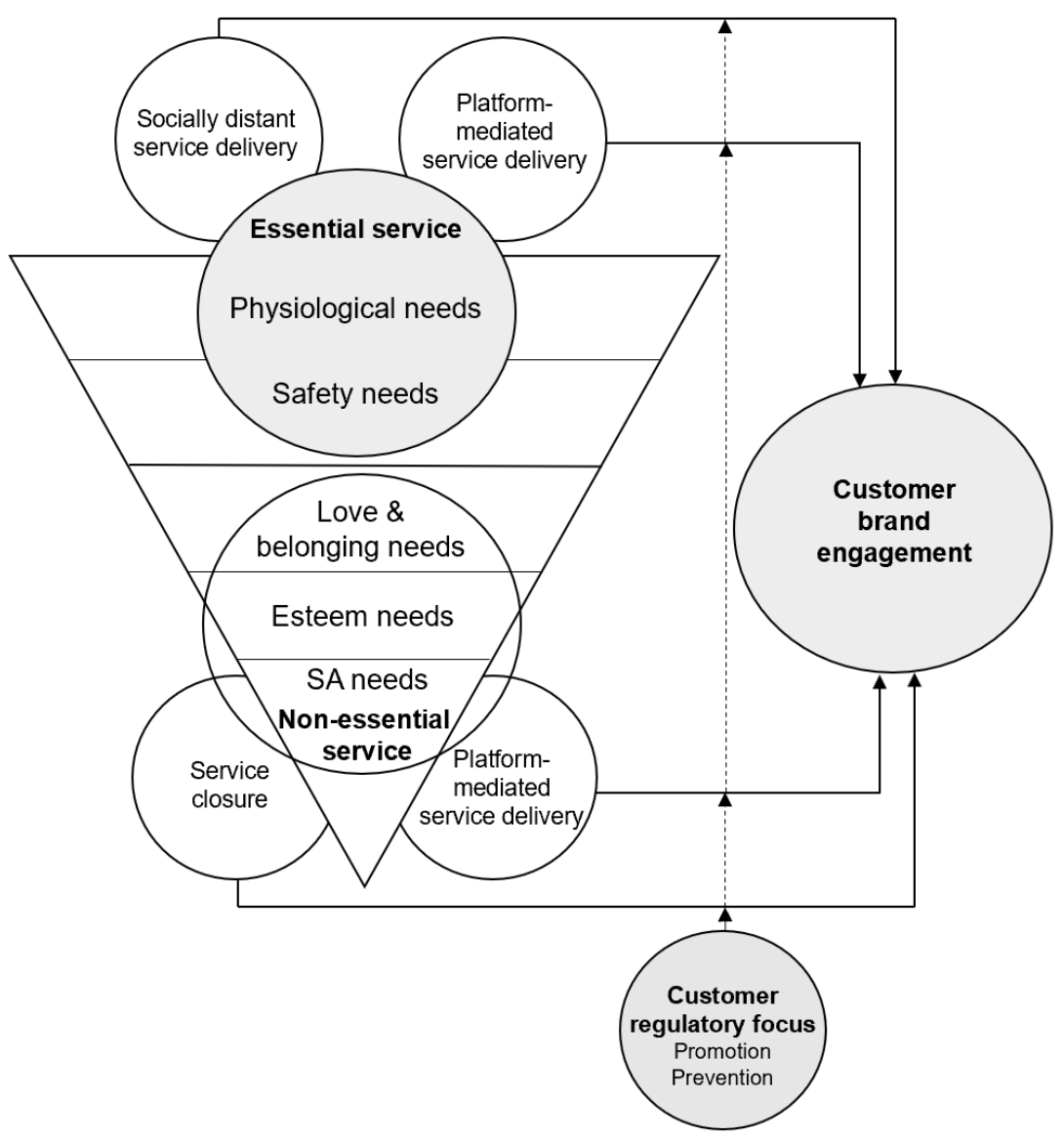

Note - SA needs: Self-actualization needs. 


\section{References}

Alexander, M., Jaakkola, E., and Hollebeek, L. (2018), "Zooming out: Actor engagement beyond the dyadic," Journal of Service Management, Vol. 29 No. 3, pp. 333-351.

Baker, M. (2020), "Characterizing occupations that cannot work from home: A means to identify susceptible worker groups during the COVID-19 pandemic," MedRxiv, DOI: https://doi.org/10.1101/2020.03.21.20031336.

Beck, L., Clark, M. and Macky, K. (2020), “Demystifying consumer digital cocreated value,” Working paper.

Beckers, S., Van Doorn, J. and Verhoef, P. (2018), "Good, better, engaged? The effect of companyinitiated customer engagement behavior on shareholder value," Journal of the Academy Marketing. Science, Vol. 46, pp. 366-383.

Békés, V. and Aafjes-Van Doorn, K. (2020), "Psychotherapists' attitudes toward online therapy during the COVID-19 pandemic," Journal of Psychotherapy Integration, Vol. 30 No. 2, pp. 238-247.

Bowden, J. (2009), "The process of customer engagement: A conceptual framework," Journal of Marketing Theory and Practice, Vol. 17 No. 1, pp. 63-74.

Breidbach, C., Brodie, R. and Hollebeek, L. (2014), "Beyond virtuality: From engagement platforms to engagement ecosystems," Managing Service Quality, Vol. 24 No. 6, pp. 592-611.

Brodie, R., Hollebeek, L, Ilic, A., and Juric, B. (2011), "Customer engagement: Conceptual domain, fundamental propositions \& implications for research in service marketing," Journal of Service Research, Vol. 14 No. 3, pp. 252-271.

Brodie, R., Juric, B., Ilic, A. and Hollebeek, L. (2013), "Consumer engagement in a virtual brand community: An exploratory analysis," Journal of Business Research, Vol. 66 No. 1, pp. 105114.

CapGemini (2020), “The consumer and COVID-19," Accessed (Apr 26, 2020) at: https://www.capgemini.com/research/the-consumer-and-covid-19/.

Clark, M., Lages, C., and Hollebeek, L. (2020), "Friend or foe? Customer engagement's value-based effects on fellow customers and the firm," Journal of Business Research, In press, DOI: https://doi.org/10.1016/j.jbusres.2020.03.011.

Das, G. (2016), "Understanding the role of regulatory focus in e-tailing activities," Journal of Services Marketing, Vol. 30 No. 2, pp. 212-222.

Do, D., Rahman, K., and Robinson, L. (2020), "Determinants of negative customer engagement behaviors," Journal of Services Marketing, Vol. 34 No. 2, pp. 117-135.

Eberhardt, W., Brüggen, E., Post, T., and Hoet, C. (2020), "Online communication in a low involvement setting," Working paper, International Journal of Research in Marketing.

Furrer, O., Kerguignas, J., Delcourt, C., and Gremler, D. (2020), "Twenty-seven years of service research: A literature review and research agenda," Journal of Services Marketing, DOI: 10.1108/JSM-02-2019-0078.

Gambrel, P. and Cianci, R. (2003), "Maslow's hierarchy of needs: Does it apply in a collectivist culture," Journal of Applied Management and Entrepreneurship, Vol. 8 No. 2, pp. 143-161.

Goffman, E. (1969), Strategic Interaction, University of Pennsylvania Press.

Groeger, L., Moroko, L., and Hollebeek, L. (2016), "Capturing value from non-paying consumers' engagement behaviours: Field evidence and development of a theoretical model," Journal of Strategic Marketing, Vol. 24 No. 3-4, pp. 190-209.

Gupta, S., Pansari, A. and Kumar, V. (2018), "Global customer engagement," Journal of International Marketing, Vol. 26 No. 1, pp. 4-29.

Hambrick, D. (1984), "Taxonomic approaches to studying strategy: Some conceptual and methodological issues," Journal of Management, Vol. 10 No. 1, pp. 27-41.

Hammedi, W., Kandampully, J., Zhang, T., and Bouquiaux, L. (2015), "Online customer engagement: Creating social environments through brand community constellations," Journal of Service Management, Vol. 26 No. 5, pp. 777-806. 
Harrigan, P., Evers, U., Miles, M. and Daly, T. (2018), "Customer engagement and the relationship between involvement, engagement, self-brand connection and brand usage intent," Journal of Business Research, Vol. 88 No. July, pp. 388-396.

Heard, S. (2020), "TVNZ is broadcasting free-to-air Les Mills fitness classes during the lockdown," Accessed (March 29, 2020): https://concreteplayground.com/auckland/travel-leisure/tvnz-isbroadcasting-free-to-air-les-mills-fitness-classes-during-the-lockdown.

Heymann, D. and Shindo, N. (2020), "COVID-19: What is next for public health?" The Lancet, Vol. 395 No. 10224, P542-545.

Higgins, E. (1997), "Beyond pleasure and pain," American Psychologist, Vol. 52 No.12, pp. 12801300.

Higgins, E., Friedman, R., Harlow, R., Idson, L., Ayduk, O., and Taylor, A. (2001), "Achievement orientations from subjective histories of success: Promotion pride versus prevention pride," European Journal of Social Psychology, Vol. 31 No.1, pp. 3-23.

Higgins, E. and Scholer, A. (2009), "Engaging the consumer: The science and art of the value creation process," Journal of Consumer Psychology, Vol. 19 No. 2, pp. 100-114.

Hollebeek, L. (2011a), "Demystifying customer brand engagement: Exploring the loyalty nexus," Journal of Marketing Management, Vol. 27 No. 7-8, pp. 785-807.

Hollebeek, L. (2011b), "Exploring customer brand engagement: Definition and themes," Journal of Strategic Marketing, Vol. 19 No. 7, pp. 555-573.

Hollebeek, L. (2013), "The customer engagement/value interface: An exploratory investigation," Australasian Marketing Journal, 21(1), 17-24.

Hollebeek, L. (2018), "Individual-level cultural consumer engagement styles: Conceptualization, propositions, and implications," International Marketing Review, Vol. 35 No. 1, pp. 42-71.

Hollebeek, L., Andreassen, T., Smith, D., Grönquist, Karahasanovic, A., and Marquez, A. (2018), "Service innovation actor engagement: An integrative model," Journal of Services Marketing, Vol. 32 No. 1, pp. 95-100.

Hollebeek, L., Clark, M., Andreassen, T., Sigurdsson, V. and Smith, D. (2020), "Virtual reality through the customer journey: Framework and propositions," Journal of Retailing \& Consumer Services, In press, DOI: https://doi.org/10.1016/j.jretconser.2020.102056.

Hollebeek, L. and Chen, T. (2014), "Exploring Positively- versus negatively-valenced brand engagement: A conceptual model," Journal of Product \& Brand Management, Vol. 23 No. 1, pp. 62-74.

Hollebeek, L., Glynn, M. and Brodie, R. (2014), "Consumer brand engagement in social media: Conceptualization, scale development and validation," Journal of Interactive Marketing, Vol. 28 No. 2, pp. 149-165.

Hollebeek, L., Juric, B., and Tang, W. (2017), "Virtual brand community engagement practices: A refined typology and model," Journal of Services Marketing, Vol. 31 No. 3, pp. 204-217.

Hollebeek, L., Srivastava, R., and Chen, T. (2019), "S-D logic-informed customer engagement: Integrative framework, revised fundamental propositions, and application to CRM," Journal of the Academy of Marketing Science, Vol. 47 No. 1, pp. 161-185.

Jacoby, J. and Kaplan, L. (1972), "The components of perceived risk," In: Venkatesan, V. (Ed.), Proceedings of the Third Annual Conference of the Association for Consumer Research, Chicago, IL: Association for Consumer Research, pp. 382-393.

Juric, B., Smith, S. and Wilks, G. (2016), "Negative customer brand engagement: An overview of conceptual and blog-based findings," In: Brodie, R., Hollebeek, L. and Conduit, J. (Eds.), Customer Engagement: Contemporary Issues and Challenges, Routledge, pp. 272-286.

Karpen, I. and Conduit, J. (2020), "Engaging in times of COVID-19 and beyond: Theorizing customer engagement through different paradigmatic lenses," Journal of Service Management, In press, DOI: https://doi.org/10.1108/JOSM-05-2020-0156. 
Kasabov, E. and Da Cunha, A. (2014), "Re-conceptualising call-centres as sites of control: The insider perspective," European Journal of Marketing, Vol. 48 No. 1/2, pp. 25-46.

Kasabov, E. and Warlow, A. (2010), The Compliance Business and Its Customers: Gaining Competitive Advantage by Controlling Your Customers, Springer.

Khan, I., Fatma, M., Islam, J., and Rahman, Z. (2020), "Brand engagement and experience in online services," Journal of Services Marketing, Vol. 34 No. 2, pp. 163-175.

KPMG (2020), "Impact of COVID-19 on the Nigerian consumer and industrial markets," Accessed (Aug 1, 2020) at: https://assets.kpmg/content/dam/kpmg/ng/pdf/advisory/impact-of-covid-19on-the-nigerian-consumer-markets-sector.pdf.

Kumar, V., Rajan, B., Gupta, S., and Dalla Pozza, I. (2019), "Customer engagement in service," Journal of the Academy of Marketing Science, Vol. 47 No. 1, pp. 138-160.

Lee, Y., In, J., and Lee, S. (2020), "Social media engagement, service complexity, and experiential quality in US hospitals," Journal of Services Marketing, DOI: https://doi.org/10.1108/JSM-092019-0359.

Letheren, K., Russell-Bennett, R., Mulcahy, R., and McAndrew, R. (2019), "Rules of (household) engagement: Technology as manager, assistant, and intern," European Journal of Marketing, Vol. 53 No. 9, pp. 1934-1961.

Liberman, N., Molden, D., Idson, L. and Higgins, E. (2001), "Promotion and prevention focus on alternative hypotheses: Implications for attributional functions," Journal of Personality and Social Psychology, Vol. 80 No. 1, pp. 5-18.

Lin, Q., Zhao, S., Gaod, D., Lou, Y., Yang, S., Musa, S., Wang, M., Caig, Y., Wang, W., Yangh, L. and Hee, D. (2020), "A conceptual model for the coronavirus disease 2019 (COVID-19) outbreak in Wuhan, China with individual reaction and governmental action," International Journal of Infectious Diseases, Vol. 93, pp. 211-216.

Ma, X., Vervoort, D., Reddy, C., Park, K., and Masaka, E. (2020), "Emergency and essential surgical healthcare services during COVID-19 in low- and middle-income countries: A perspective," International Journal of Surgery, In press, DOI: https://doi.org/10.1016/j.ijsu.2020.05.037.

Markowitz, Y., Boer, D. and Van Dick, R. (2014), "Economic crisis and the employee: The effects of economic crisis on employee job satisfaction, commitment, and self-regulation," European Management Journal, Vol. 32 No. 3, pp. 413-422.

Marston, H., Musselwhite, C., and Hadley, R. (2020), "COVID-19 vs social isolation: The impact technology can have on communities, social connections and citizens," Ageing Issues, British Society of Gerontology.

Maslow, A. (1943), “A theory of human motivation," Psychological Review, Vol. 40 No. 4, pp. 70396.

Maslow, A. (1954), Motivation and Personality, New York: Harper \& Row.

Micu, C. and Chowdhury, T. (2010), "The effect of ageing and time horizon perspective on consumers' response to promotion versus prevention focus advertisements," International Journal of Advertising, Vol. 29 No. 4, pp. 621-642.

Mosteller, J. and Poddar, A. (2017), "To share and protect: Using regulatory focus theory to examine the privacy paradox of consumers' social media engagement and online privacy protection behaviors," Journal of Interactive Marketing, Vol. 39 No. 8, pp. 27-38.

Oertzen, A., Odekerken-Schröder, G., and Mager, B. (2020), "Driving users' behaviours and engagement in co-creating services," Journal of Services Marketing, DOI: https://doi.org/10.1108/JSM-06-2019-0244.

Parasuraman, A. (2000), "Technology readiness index (TRI): A multiple-item scale to measure readiness to embrace new technologies," Journal of Service Research, Vol. 2 No 4, pp. 307320.

Porpiglia, F., Checcucci, E., Autorino, R., Amparore, D., Cooperberg, M., Ficarra, V. and Novara, G. (2020), "Traditional and virtual congress meetings during the COVID-19 pandemic and the 
post-COVID-19 era: Is it time to change the paradigm?" European Urology, In press, DOI: 10.1016/j.eururo.2020.04.018.

Ramaswamy, V. and Ozcan, K. (2016), "Brand value co-creation in a digitalized world: An integrative framework and research implications," International Journal of Research in Marketing, Vol. 33 No. 1, pp. 93-106.

Roggeveen, A. and Sethuraman, R. (2020), "How the COVID-19 pandemic may change the world of retailing," Journal of Retailing, Vol. 96 No. 2, pp. 169-171.

Rosenbaum, M. and Massiah, C. (2007), "When customers receive support from other customers: Exploring the influence of intercustomer social support on customer voluntary performance," Journal of Service Research, Vol. 9 No. 3, pp. 257-270.

Rogers, E. (1962), Diffusion of Innovations, New York: Free Press.

Russell-Bennett, R., Fisk, R., Rosenbaum, M., and Zainuddin, N. (2019), "Transformative service research and social marketing: Converging pathways to social change," Journal of Services Marketing, Vol. 33 No. 6, pp. 633-642.

Solem, B. and Pedersen, P. (2016), "The effects of regulatory fit on customer brand engagement: An experimental study of service brand activities in social media," Journal of Marketing Management, Vol. 32 No. 5-6, pp. 445-468.

Sprott, D., Beck, H., and Brady, M. (2020), "Customer engagement in robotic interactions," Working paper.

Sprott, D., Czellar, S., and Spangenberg, E. (2009), "The importance of a general measure of brand engagement on market behavior: Development and validation of a scale," Journal of Marketing Research, Vol. 46 No. 1, pp. 92-104.

Stam, K. and Stanton, J. (2010), "Events, emotions, and technology: Examining acceptance of workplace technology changes," Information Technology \& People, Vol. 23 No. 1, pp. 23-53.

Sullivan, H., Rawlinson, K., Topping, A., and Gayle, D. (2020), "Spain overtakes China as second worst-hit country by Covid-19, as it happened," Accessed (March 30, 2020: https://www.theguardian.com/australia-news/live/2020/mar/25/coronavirus-live-news-indialockdown-italy-cases-restrictions-uk-us-outbreak-australia-china-hubei-latesfitupdates?page $=$ with:block-5e7af15a8f0878a2a48a9a9f.

Tversky, A. and Kahneman, D. (1986), "Rational choice and the framing of decisions," Journal of Business, Vol. 59 No. 4, pp. 251-278.

Vargo, S. and Lusch, R. (2016), "Institutions and axioms: An extension and update of servicedominant logic," Journal of the Academy of Marketing Science, Vol. 44 No. 1, pp. 5-23.

Verleye, K., Gemmel, P., and Rangarajan, D. (2014), "Managing engagement behaviors in a network of customers and stakeholders: Evidence from the nursing home sector," Journal of Service Research, Vol. 17 No. 1, pp. 68-84.

Vilnai-Yavetz, I. and Levina, O. (2018), "Motivating social sharing of e-business content: Intrinsic motivation, extrinsic motivation, or crowding-out effect?" Computers in Human Behavior, Vol. 79 No. 2, pp.181-191.

Viswanathan, V., Hollebeek, L., Malthouse, E., Maslowska, E., Kim, S.J. and Xie, W. (2017), "The dynamics of consumer engagement with mobile technologies," Service Science, Vol. 9 No. 1, pp. 36-49.

Vivek, S., Beatty, S. and Morgan, R. (2012), "Customer engagement: Exploring customer relationships beyond purchase," Journal of Marketing Theory and Practice, Vol. 20 No. 2, pp. 127-145.

Vivek, S., Beatty, S., Dalela, V., and Morgan, R. (2014), "A generalized multidimensional scale for measuring customer engagement," Journal of Marketing Theory and Practice, Vol. 22 No. 4, pp. 401-420.

Ward, M., Chandler, J., Pels, J. (2019), "Resource integration in resource-poor environments," Working paper. 
Werth, L. and Foerster, J. (2007), "How regulatory focus influences consumer behavior," European Journal of Social Psychology, Vol. 37 No. 1, pp. 33-51.

WHO - World Health Organization (2020),"Clinical management of severe acute respiratory infection (SARI) when COVID-19 disease is suspected: Interim guidance," Accessed (March 7, 2020): https://www.who.int/publications-detail/clinical-management-of-severe-acute-respiratoryinfection-when-novel-coronavirus-(ncov)-infection-is-suspected.

Wilder-Smith, A. and Freedman, D. (2020), "Isolation, quarantine, social distancing and community containment: Pivotal role for old-style public health measures in the novel coronavirus (2019nCoV) outbreak," Journal of Travel Medicine, Vol. 1 No. 4, pp. 1-4.

Yuan, D., Lin, Z., Fillieri, R., Liu, R. and Zheng, M. (2020), "Managing the product-harm crisis in the digital era: The role of consumer online brand community engagement," Journal of Business Research, In press, DOI: https://doi.org/10.1016/j.jbusres.2020.04.044. 